\title{
Rockfall Hazard Rating System(s) in Saudi Arabia - A Review
}

\author{
Adnan M. Aqeel ${ }^{1,2}$ \\ ${ }^{1}$ College of Science, Taibah University, Madina, Saudi Arabia \\ ${ }^{2}$ College of Science, Sana'a University, Sana'a, Yemen \\ Correspondence: Adnan Aqeel, College of Science, Taibah University, Madina, 41477, Saudi Arabia. Tel: 966-14- \\ 8618888-1309. E-mail: ben_aqeel_2005@yahoo.com
}

Received: August 3, 2018

Accepted: September 10, 2018

Online Published: November 9, 2018

doi:10.5539/jgg.v10n4p1

URL: http://dx.doi.org/10.5539/jgg.v10n4p1

\begin{abstract}
Slope instability along highways in mountainous areas is not only a major hazard for lives and passing vehicles but also may hinder traffic for long period and thus create significant economic loss. The most common type of slope instability failures in such areas is rockfalls. Many qualitative rockfall hazard rating systems (RHRSs) have been developed across the world. However, the Middle East almost lacks to such systems. For instance, in Saudi Arabia, which has the largest economy in the region, only one system of rockfall hazard rating system (RHRS-SA) has been developed up to now. This paper aimed to critically review this system. Some drawbacks were found in the RHRS-SA. However, the main disadvantage was that the final rating score of risk is not consistent with risk definition. In sum, the remarkable findings of this review can be accounted either for any future modifications for the RHRS-SA or to develop a new rockfall hazard rating system but for a specific area(s) in Saudi Arabia.
\end{abstract}

Keywords: hazard rating system, Jazan province, risk, rockfall, Saudi Arabia

\section{Introduction}

Rockfall is a significant sporadic and unpredictable natural hazard that usually affects highways and roads which are cut in mountainous areas (Bunce, Cruden, \& Morgenstern, 1997; Hungr, Evans, \& Hazzard, 1999). Rockfall is one of the most common slope instability types in the world (Badger \& Lowell, 1992; Keefer, 2002; Guzzetti, Reichenbach, Cardinali, Ardizzone, \& Galli, 2003; Ferrari, Giani, \& Apuani, 2013). Rockfall can be defined as a type of small scale landslide in which a single rock or boulder or a small group of independently moving rocks become dislodged from an exposed rock slope face and moves downward under the action of gravity (Varnes, 1978; Ansari, Ahmed, Singh, \& Ghalayani, 2015). The falling rocks may be in the modes of free fall, rolling and/or bouncing depending on the geometry of the rock slope (Ritchie, 1963).

Even though, rockfall could not have the same level of economic risks as large scale slope failures, the number of people whom are killed by rockfall tends to be the same number of killed people by other types of rock slope instability (Hoek, 2006). To differentiate between rockfall, rockslide, and rock-avalanches, rockfall can be referred to quantitative measure describing small phenomena ranging from a few $\mathrm{m}^{3}$ up to $10,000 \mathrm{~m}^{3}$ of detached rock block events, whereas rockslide is used to describe more than $100,000 \mathrm{~m}^{3}$ and rock-avalanches can reach several millions $\mathrm{m}^{3}$ (Dussauge et al., 2002). Consequently, rockfalls can cause a disaster as that one happened in Al-Dhafir village in Sana'a, Yemen in 2008 where the entire village was destroyed and resulting in loss of life of 65 persons (Aqeel, Maerz, \& Anderson, 2014).

Most of the highway rockfall incidents are difficult to be analyzed using conventional slope stability analysis methods such as kinematic analysis (Maerz, Youssef, Pradhan, \& Bulkhi, 2015). Franklin and Senior (1997) reported that 278 out of 415 analyzed rockfall incidents along highways in North Ontario involved failure mechanisms that were more complex. This type of failure mechanism is known as raveling which is a timedependent process and where hazard cannot be recognized until rock failures take place (Maerz et al., 2015). Subsequently, a rockfall hazard rating system is required to identify and develop a workable schedule, a systematic system, for highways and roads along rock cut (Youssef, Maerz, \& Fritz, 2003).

Several qualitative rockfall hazard rating systems (RHRSs) have been developed during the past three decades and are in use by different authorities all over the world such as: Oregon-RHRS (Pierson \& Van-Vickle, 1993), Rockfall Hazard Rating System for Ontario, Canada (RHRON) (Franklin \& Senior, 1997), New Priority Classification Systems (NPCSs) for Hong Kong, China (Wong, 1998), Highway Slope Instability Management System (HiSIMS) 
for Tennessee (Miller, 2003),Missouri Rockfall Hazard Rating System (MORFH-RS, Maerz \& Youssef, 2004), Modified Rockfall Hazard Rating System of Italy (mRHRS-Italy, Budetta, 2004), Rock Cut Stability Assessment of Spain (RCSA, Uribe-Etxebarria, Morales, Urarte, \& Ibarra, 2005), Rockfall Hazard Rating Matrix for Ohio (RHRM, Woodard \& Shakoor, 2005), Utah Department of Transportation-Rockfall Hazard Rating System (DOTRHRS, Pack, Boie, Mather, \& Farrell, 2006), New York DOT Rock Slope Rating Procedure (New York Department of Transportation [NYDOT], 2007), Colorado Rockfall Hazard Rating System (CRHRS, Russell, Santi, \& Humphrey, 2008), and modified Colorado-RHRS (Santi, Christopher, Jerry, \& Jessica, 2009).

All the aforementioned rockfall assessment systems are qualitative systems, which being more popular and easyto-use compared to quantitative systems. They mainly deal with both loss of life and property damage. The vast majority of these systems have been developed in the USA (Pantelidis, 2011). Most of the RHRSs in the USA were adopted or modified the Rockfall Hazard Rating System (RHRS) developed by Pierson and Van-Vickle (1993) or have used a combination of this system and the Highway Rockfall Hazard Rating System (HRHRS) developed by Wyllie (1987).

In the Middle East, however, only one rockfall hazard rating system has been recently developed but for Saudi Arabia. This system is known as the Rockfall Hazard Rating System of Saudi Arabia (RHRS-SA) which was developed by Maerz and others (2015). It is basically developed based on both of the Modified Colorado rockfall hazard rating system (Santi et al., 2009) and the Missouri rockfall hazard rating system (Maerz, Youssef, \& Lauer, 2004; Maerz, Youssef, \& Fennessey, 2005). As a general rule, this developed system has pros and cons.

The main objective of this research is to carefully review this system with emphasis on disadvantage aspects. Therefore, any future modifications for the RHRS-SA can be built on the findings of this research. Furthermore, the results of this review can be significantly taken in consideration during developing any other systematic rockfall hazard rating systems in the mountainous areas of Saudi Arabia and similar areas.

\section{General Geomorphology and Geology of Saudi Arabia}

\subsection{General Geomorphology}

Saudi Arabia is the largest country in the Arabian Peninsula with an area of about $2150000 \mathrm{~km}^{2}$. Almost two thirds of this area is a desert lands known as Arabian platform which contains Al-Rub Al-Khali desert, Al-Nafud desert, and Al-Dahna desert as shown in Figure 1. The elevation of this platform rises toward the west and the southwest where hills and mountains are the main dominant geomorphological features.

The geomorphological features of Saudi Arabia can generally be divided into four main zones as following, from west to east (Figure 1): Zone (1) is the western coastal line which extends along the Red Sea. This zone is known as Tihamah plains; Zone (2) the Arabian Shield escarpment which is distinguished by harsh mountainous nature. The elevation of some mountains in this zone can locally reach over than $3 \mathrm{~km}$ above sea level; Zone (3) is the Arabian platform which is largely covered by desert lands; and finally Zone (4) is the eastern coastal line along the Arabian Gulf. ArcGIS 10.2 Software was used to depict these zones as shown in Figure 1.

\subsection{General Geology}

In terms of geology, Saudi Arabia can be generally divided into four major distinct terrains as follows: i) the Precambrian Proterozoic Arabian Shield which is consist of metamorphic and plutonic rocks; ii) the Phanerozoic Arabian platform which composes of sedimentary rock cover, dipping gently eastward away from the shield; iii) the Tertiary basaltic plateaus (Harrats) which mainly overlies the shield; and iv) the narrow Red Sea coastal plain of Tertiary and Quaternary sedimentary rocks and coral reefs (Saudi Geology Survey [SGS], 2017) as illustrated in Figure 2.

The Arabian Shield terrain, the western part, occupies almost one third of the total area of Saudi Arabia with a rough area of $740000 \mathrm{~km}^{2}$ (Figure 2). It consists of Precambrian rocks, mainly igneous and metamorphic, and largely overlain by younger volcanic rocks (Bamousa, 2011).

\section{Rock Slope Instability Studies in Saudi Arabia}

The Arabian Shield is the terrain which has a harsh and a complex mountainous nature. Hence, most of highways and roads have to be constructed traversing through hills and mountains in this terrain. Some researches were done for slope stability investigation only in this terrain of Saudi Arabia (Sadagah, 2007, 2008, 2009, 2010; Youssef, Maerz, \& Al-Otaibi, 2012; Youssef, 2015; Youssef, Al-Kathery, \& Pradhan, 2015a, Youssef, Pradhan, Jebur, \& ElHarbi 2015b, Youssef, Pradhan, Pourghasemi, \& Abdullah, 2015c, Youssef, Pradhan, Al-Kathery, Bathrellos, \& Skilodimou, 2015d; Maerz et al., 2015). However, a few of those studies were in the field of rockfall hazard assessment either by using rockfall simulation programs such as Colorado Rockfall simulation program (Sadagah, 
2007, 2008, 2009) and RockFall simulation software, produced by RocScience Inc. 2012, (Youssef et al., 2015d) or by using Colorado Rockfall Hazard Rating System (CRHRS), developed by Russell and others (2008), (Youssef et al., 2012). Accordingly, none of all of aforementioned studies has developed a local rockfall hazard rating system adopted for local nature of Saudi Arabia.

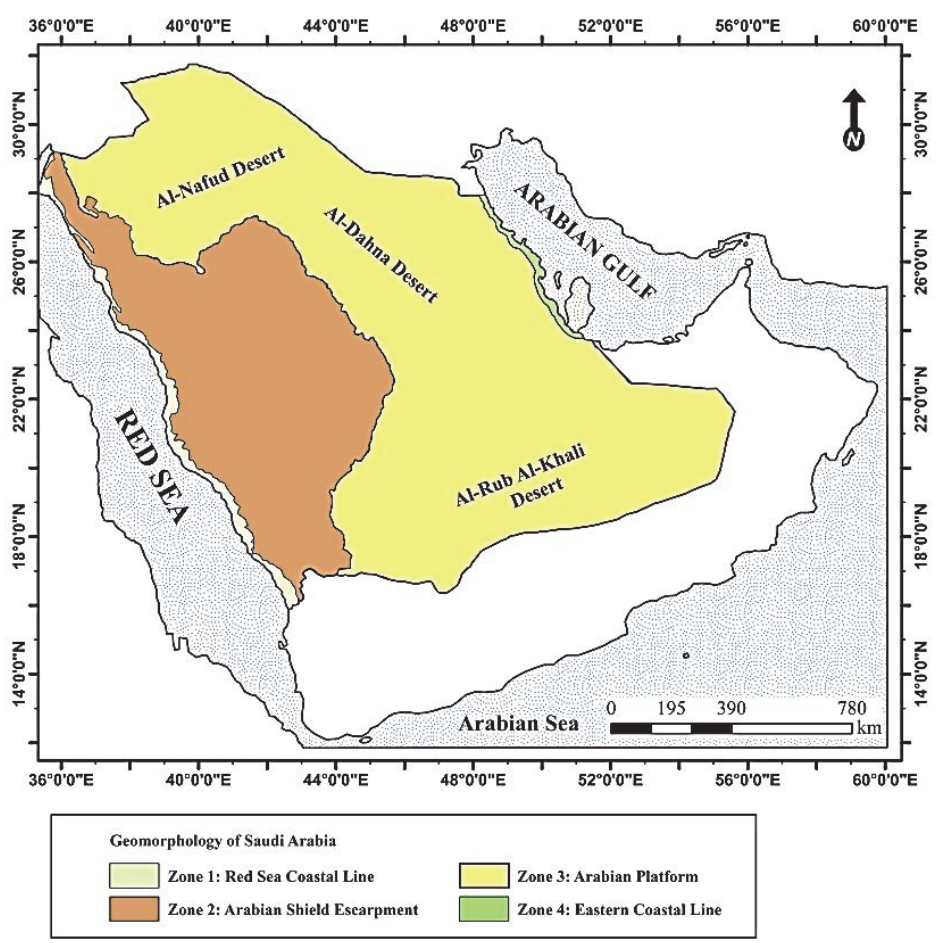

Figure 1. General geomorphology of Saudi Arabia

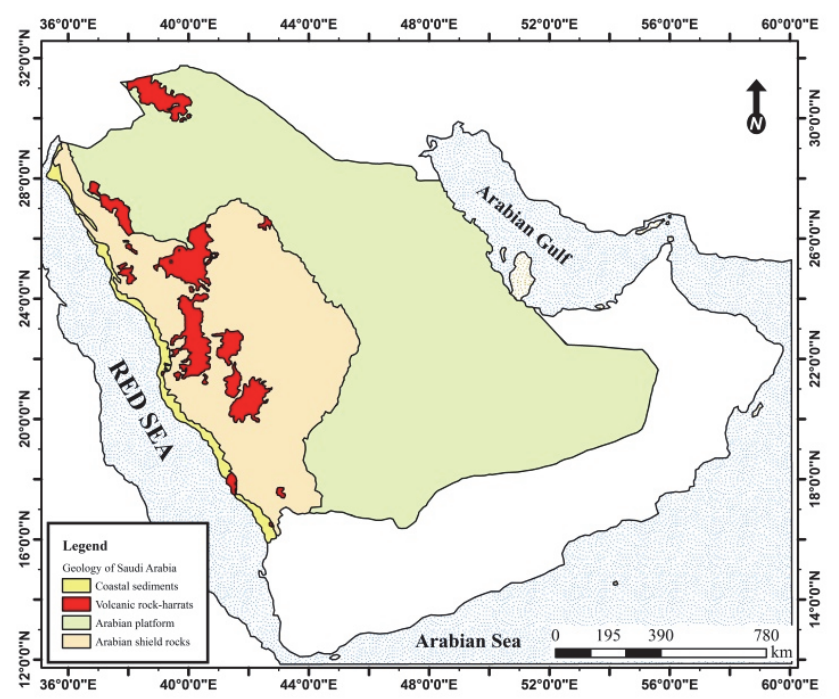

Figure 2. General geology of Saudi Arabia

The only attempt, which is the first, to develop a rockfall hazard rating system for local Saudi nature was made by Maerz and others in 2015. They developed what is known as the Rockfall Hazard Rating System of Saudi Arabia (RHRS-SA) but based on the the Missouri rockfall hazard rating system (Maerz et al., 2004, 2005) and the Modified Colorado rockfall hazard rating system (Santi et al., 2009). In one side, this system was a great attempt and good to-some-extent approach to be used for rockfall events inventory in Saudi Arabia; but in other side, it 
has some disadvantages. Accordingly, the main objective of this research is to review this system; therefore, the following section will discuss this issue.

\subsection{Description of the Rockfall Hazard Rating System of Saudi Arabia (RHRS-SA)}

The RHRS-SA was designed to cost-effectively determine the need for maintenance on slope cuts and to reduce the risk of vehicle damage and traffic delays resulting from slope failures (Maerz et al., 2015). Although this system of rockfall hazard rating was developed based on both of the Modified Colorado rockfall hazard rating system (Modified-CRHRS) (Santi et al., 2009) and the Missouri rockfall hazard rating system (MORFH-RS; Maerz et al., 2004, 2005), the major part of it was based on MORFH-RS. Selection factors of hazard rating, in this system, was according to the requirement of the geology and the structures of the investigated area, which is only Jazan province (Figure 3).

Briefly, this system classified the selected factors for risk analysis into two main types: the factors of failure hazard (Hazard) and the factors of the failure impact (Impact or Consequences). Furthermore, the factors of failure hazard are classified into four groups: slope factors, climate and water factors, rock type factors, and discontinuity factors. In contrast, the factors of the failure impact are classified into three groups: slope factors, ditch factors, and road factors. In addition, it used a failure hazard rating scale for each factor ranges from 2 (the minimum value) to 16 (the maximum value) as $2,2^{2}, 2^{3}$, and $2^{4}$. As a result, a total of four categories of hazard degree are identified ( 2 , 4,8 , and 16). For the degree of the impacts (the consequences), it classify them into five categories of risk levels: low (L), low to medium (L-M), medium (M), medium to high (M-H), and high (H).

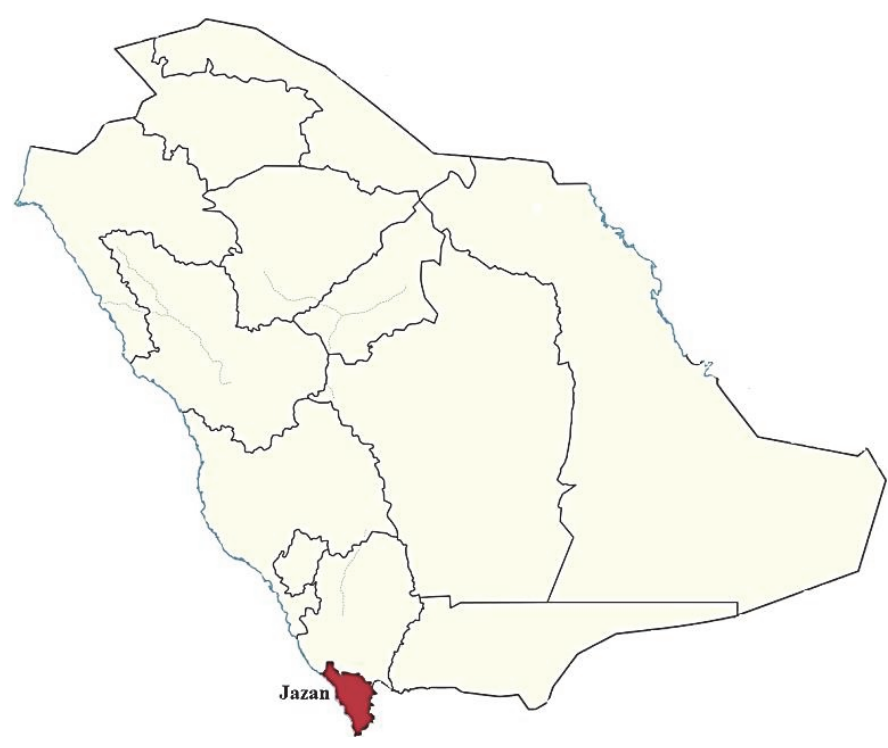

Figure 3. Jazan province location

\subsection{Evaluation of the RHRS-SA}

Although the RHRS-SA is the first attempt of developing a rockfall hazard rating system in Saudi Arabia, it has critical drawbacks to which this research is concerning and aiming. These disadvantages are listed and discussed below.

\subsubsection{Calculating Risk}

The main disadvantage is the final rating score reflecting risk is derived from the summation of scores of an amalgam of the potential hazard and the potential consequences of slope failure. This practice is not consistent with the definition of risk, where risk is defined as the production of multiplication of both the hazard and the consequence (Risk = Hazard x Consequences). Both of Modified-CRHRS and MORFH-RS on which RHRS-SA has been developed miscalculate risk level (Pantelidis 2011). Accordingly, underestimation for the resulting risk will occur.

\subsubsection{Classifying Hazard Degrees and Risk Levels}

One other problem which can be noticed in the RHRS-SA is that the number of hazard categories (four categories: 
$2,4,8,16$ ) does not match and is not consistent with the number of the consequences risk categories (five categories: L, L-M, M, M-H, H) which may cause miscalculation and misinterpretation for the final calculated risk level. Moreover, the overlapping between consequence risk levels L-M and M as well as M-H and $\mathrm{H}$ which can lead to confusion in terms of taking decision and implementing an action. They should be more accurate and direct such as: L, M, H, Very H or as No Rik, Low Risk, Moderate Risk, and High Risk.

\subsubsection{Replicating of Some Rating Factors}

Another drawback is that some factors were used more than once either within the hazard factors or within the consequence (impact) factors which may cause overestimation, or even an exaggeration, in results and affects negatively cost-effectiveness measures. For instance, block size was used as a factor for each of rock type, discontinuity, and slope. Moreover, block shape was used as a factor for both block in matrix and slope. In other cases, some factors (such as the slope angle and block size) were duplicated by using them in both the hazard of failure and the impact of failure factors which will increase the score of risk and thus affect the cost-effectiveness of proposed remediation and mitigation measurements. To overcome this disadvantage, factors of slope failure hazards should be identified and specified with no repetition or duplication within those factors of slope failure impacts.

\subsubsection{Exaggeration of Some Rating Factors}

Ditch characteristic factors were given exaggerated scores of risk since each of ditch width, ditch volume, and ditch shape treated separately as individual factors. Accordingly, the rate for ditch ranges between 1 and 36 . However, the volume is basically calculated based on the width, length, and depth dimensions of the ditch. These three dimensions are which generally determine the shape. Therefore, scoring only the volume of ditch would be more reliable than what was used in the RHRS-SA.

\subsubsection{Underestimation the Hydraulic Conditions}

The effect of water (hydraulic conditions) in slope materials was given much lower rate than it should be in this system. It was given for the whole rock mass regardless the type of rock even though the presence of percolating water can dramatically reduce strength of the rock materials and increase angle of repose depending on rock type (Table 1). A research by Wong, Maruvanchery, \& Liu (2016) stated that sedimentary rocks usually experience lower uniaxial compressive strength (UCS) when are wet or saturated compared with massive crystalline igneous rocks. In general, sedimentary rocks may lose more than $40 \%$ of their USC while massive igneous rocks could lose up to $10 \%$ of their strength. For diabase and vesicular volcanic rocks, the UCS can dramatically decreases up to $50 \%$ (Wong et al., 2016). In more details, sandstone can have $45-80 \%$ reduction of its uniaxial compressive strength (Price, 1960) as well as claystone (shale and mudstone) may lose 80-90\% (Jumikis 1966). Vásárhelyi (2005) stated that limestones can lose $50-70 \%$ of its uniaxial strength when it is wetted. In contrast, slate can lose $10-20 \%$ of UCS while other metamorphic rocks may lose 30-70 \% (Wong et al., 2016). Subsequently, with no taking in consideration the effect of hydraulic condition on the uniaxial compressive strength of each rock type or bed separately, underestimation of resulting risk scores will certainly occur. Therefore, the value of the UCS should be, first, adjusted as well as the factor hazard rating based on the hydraulic condition in the area of interest.

\subsubsection{Rock Characterization}

Weathering play a major role in characterizing rocks since it can dramatically reduce the uniaxial strength of a rock (UCS) (such as granite) to a degree, in some cases, close to the compressive strength of shale or even soil. In other words, the using of rock type factor could be useless and may results in obtaining inaccurate resulting risk scores and analysis. Accordingly, the author of this research suggests using UCS as a rock characterization to get more reliable and accurate estimated risk level. The type of rock can be taken in account only to estimate the effect of the presence of water on the uniaxial strength of the rock as explained aforementioned.

\subsubsection{Weathering Grade in the RHRS-SA}

Weathering grade was rated individually for each rock type in the RHRS-SA. However, this way of rating is not practical way to score two different degrees of weathering for different rock types at the same rock cut or zone. To justify this, let's suppose there is a rock cut composes of a sequence of a rock bed of silt overlies a rock bed of granite. The weathering will surely have much more effect on the silt compared to the granitic bedrock. As a result, scoring the weathering grade for both the beds (the silt and the granite) may lead to increase the probability of slope failure regardless of the weathering grade of the granitic bed. Consequently, the author suggest that when there is more than one type of bedrocks at the same rock cut, the best is to consider only the highest score of weathering grade in order to avoid underestimation of risk analysis.

\subsubsection{Vegetation Cover Scoring}


The other drawback is that the RHRS-SA used vegetation factor for rock beds and for decomposed rocks (highly weathered rocks) and soils at the same level of scoring and risk analysis. However, vegetation has two different opposite roles in slope stability. While the occurrence of vegetation cover is favorable in soil mass slopes since it holds soil particles, it has adversely effects on rock slopes causing cracks and fractures that can lead to rock slope failures. Therefore, scoring vegetation cove in soil is opposite to the scoring scale for vegetation cover in bedrocks.

\subsubsection{Not Considering Facilities Nearby}

Another issue is that the RHRS-SA did not consider the presence of any facility in the failure zone (on the top, at the toe, and/or near the toe of the slope). Accounting such factor will certainly give highly priority for correction measures even for low failure hazard since the potential failure consequences could be highly undesirable.

\subsubsection{Economic factor}

Both of MORFH-RS and Modified-CRHRS deal only with loss of life and thus consider only the human safety factor (Pantelidis, 2011) without any accounting for economic loss.

\subsubsection{The Area Size on which the RHRS-SA was Applied and Developed}

The last point is that the RHRS-SA was developed based on investigating rockfall events only in Jazan (or Jizan) province, which is located at the southwestern part of Saudi. Jazan is the second smallest province, after Al-Baha province, with an area of about $13457 \mathrm{~km}^{2}$. This area represents about $1.82 \%$ and $0.60 \%$ of the entire area of the Arabian Shield and the Saudi Arabia, respectively (Figure 3). Although the Arabian Shield is generally a mountainous terrain, its climate varies dramatically between the northern regions where snow falls in winter, the middle regions where precipitation and rainfall is less, and the southern regions where rainfall is higher and climate is warmer. Consequently, the RHRS-SA should not have been generalized as it is applicable for the whole area of Saudi Arabia. It could be applicable, but after modification, for the entire southwestern part of the Saudi since the areas of this part have almost the same geology, structures, geomorphology, and climate.

Table 1. The effect of the presence of water on the uniaxial strength of rocks

\begin{tabular}{lcc}
\hline \multicolumn{1}{c}{ Rock Type } & Uniaxial Strength Reduction \% & Reference \\
\hline Sedimentary (in general) & $>40 \%$ & (Wong et al., 2016) \\
\hline Sandstone & $40-80 \%$ & (Price, 1960) \\
\hline claystone & $80-90 \%$ & (Jumikis, 1966) \\
\hline Limestone & $50-70 \%$ & (Vásárhelyi, 2005) \\
\hline Massive Igneous & $\leq 10 \%$ & (Wong et al., 2016) \\
\hline Diabase and Vesicular volcanic & $\leq 50 \%$ & (Wong et al., 2016) \\
\hline foliated metamorphic & $10-70 \%$ & (Wong et al., 2016) \\
\hline
\end{tabular}

\section{Conclusions}

The RHRS-SA is a qualitative system for assessment and rating rockfall event hazards. This system can be considered the first developed one for highways and roads in Saudi Arabia. Even though it is a good attempt in the field of rockfall hazard inventory and assessment, it has some significant drawbacks to which should be pointed out. The major disadvantage is the summation of the probability hazard and probability consequence factors. This practice is not consistent with the definition of risk, which is the product of the multiplication of hazard and consequence factors, and thus resulting in underestimation for risk. In contrast, some factors are used as factors for both hazard probability and consequence probability at the same time which may cause overestimation for resulting risk. The other disadvantage is the lack of estimating the effect of hydraulic conditions on uniaxial compressive strength values of rocks. Last but not least, vegetation cover factor is used at the same level for both rock slopes and soil slopes which leads to misanalysis and misinterpretation for rockfall event risks. While vegetation is considered a stabilization method for soil or decomposed rock slopes, it is known as a biological weathering factor for rock slopes.

Finally, this RHRS-SA was developed based on field inspection for rockfall events in a small part of Saudi Arabia (Jazan Province). Therefore, it is recommended to be used only, after making modification, for the southwestern part of Saudi Arabia. In other words, after modifying the RHRS-SA, this system could be applied for rockfall 
assessment but only for the southwestern part of Saudi Arabia where geology, structures, climate, and geomorphology are almost similar.

\section{References}

Ansari, M. K., Ahmed, M., Singh, T., \& Ghalayani, I. (2015). Rainfall, A major cause for rockfall hazard along the roadways, highways and railways on Hilly Terrains in India. Engineering Geology for Society and Territory, 1, 457-460. https://doi.org/10.1007/978-3-319-09300-0_87

Aqeel, A., Maerz, N., \& Anderson, N. (2014). Mapping subvertical discontinuities in rock cuts using a $400 \mathrm{mhz}$ ground penetrating radar antenna. Arabian Journal of Geosciences, 7(5), 093-2105. https://doi.org/10.1007/s12517-013-0937-y

Badger, T. C., \& Lowell, S. (1992). Rockfall control in Washington State. In: Rockfall prediction and control and landslide case histories, Transportation research record, National research council, Washington, 1342, pp1419.

Bamousa, A. O. (2011). Infracambrian superimposed tectonics in the late Proterozoic units of mount Albah area, southern Asir Terrane, Arabian shield of Saudi Arabia. Arabian Journal of Geosciences, 6, 2035-2040. https://doi.org/10.1007/s12517-011-0490-5

Budetta, P. (2004). Assessment of rockfall risk along roads. Natural Hazards and Earth System Sciences, 4, $71-$ 81. https://doi.org/10.5194/nhess-4-71-2004

Bunce, C. M., Cruden, D. M., \& Morgenstern, N. R. (1997). Assessment of the hazard from rockfall on a highway. Canadian Geotechnical Journal, 34(3), 344-356. https://doi.org/10.1139/t97-009

Dussauge, P. C., Helmstetter, A., Grasso, J. R., Hantz, D., Desvarreux, P., \& Giraud, A. (2002). Probabilistic approach to rockfall hazard assessment: potential of historical data analysis. Natural Hazards and Earth System Sciences, 2(15-26), 15-26. https://doi.org/10.5194/nhess-2-15-2002

Ferrari, F., Giani G., \& Apuani T. (2013). Why can rockfall normal restitution coefficient be higher than one? Geological Society of Italy, 24, 122-124.

Franklin, J. A., \& Senior, S. A. (1997). The Ontario rockfall hazard rating system. Proceedings of international conference on engineering geology and the environment, 1, 647-656.

Guzzetti, F., Reichenbach, P., Cardinali, M., Ardizzone, F., \& Galli, M. (2003). The impact of landslides in the Umbria region, central Italy. Natural Hazards and Earth System Sciences, 3(5), 469-486. https://doi.org/10.5194/nhess-3-469-2003

Hoek, E. (2006). Practical rock engineering, Course notes. Evert Hoek Consulting Engineer Inc., Canada.

Hungr, O., Evans S. G., \& Hazzard J. (1999). Magnitude and frequency of rock falls and rock slides along the main transportation corridors of southwestern British Columbia. Canadian Geotechnical Journal, 36(2), 224238. https://doi.org/10.1139/t98-106

Jumikis, A. R. (1966). Some engineering aspects of Brunswick shale. In: $1^{\text {st }}$ Congress of the international society of rock mechanics, $25 \mathrm{Sep}-1$ Oct, Lisbon, Portugal

Keefer, D. K. (2002). Investigating landslides caused by earthquakes - a historical review. Surveys in Geophysics, 23(6), 473-510. https://doi.org/10.1023/A:1021274710840

Maerz, N. H., Youssef, A., \& Fennessey, T. W. (2005). New risk-consequence rockfall hazard rating system for Missouri highways using digital image analysis. Environmental and Engineering Geoscience Journal, 11, 229-249. https://doi.org/10.2113/11.3.229

Maerz. N. H., Youssef, A., \& Lauer, R. (2004). MORFH RS: A rock cut rating system for Missouri highways. The $55^{\text {th }}$ highway geology symposium, Kansas City, Missouri, Sep. 7-10, 2004, pp406-424.

Maerz. N. H., Youssef, A., Pradhan, B., \& Bulkhi, A. (2015). Remediation and mitigation strategies for rock fall hazards along the highways of Fayfa Mountain, Jazan Region, Kingdom of Saudi Arabia. Arabian Journal of Geosciences, 8(5), 2633-2651. https://doi.org/10.1007/s12517-014-1423-x

Miller, S. M. (2003). Development and implementation of the Idaho highway slope instability and management system (HiSIMS). National institute for advanced transportation technology, University of Idaho, USA.

New York Department of Transportation (NYDOT). (2007). Rock slope rating procedure: geotechnical engineering manual GEM-15. NYDOT, New York. 
Pack, R., Boie, K., Mather, S., \& Farrell, J. (2006). UDOT rockfall hazard rating system: final report and user's manual (Report UT-06.07). Utah State University, Logan.

Pantelidis, L. (2011). A critical review of highway slope instability risk assessment systems. Bulletin of Engineering Geology and the Environment, 70(3), 395-400. https://doi.org/10.1007/s10064-010-0328-5

Pierson, L. A., \& Van-Vickle, R. (1993). Rockfall hazard rating system participant's manual. SNI International Resources Inc., Phoenix, USA.

Price, N. J. (1960). The compressive strength of coal measure rocks. Colliery Engineering, 37(437), 283-292.

Ritchie, A. M. (1963). Evaluation of rock fall and its control. Highway research record 17, Highway research board, NRC, Washington, DC, pp13-28.

Rockfall Simulation Program. (2007). $1^{\text {st }}$ National American symposium on landslides: 3-8 June 2007, Vail, CO, USA, pp1414-1421.

Russell, C. P., Santi, P., \& Humphrey, J. D. (2008). Modification and statistical analysis of the Colorado rockfall hazard rating system: Report No. CDOT-2008-7, p139

Sadagah, B. H. (2007). Simulation of rockfall hazard along selected parts of Al-Baha descent highway using the Colorado rockfall simulation program, $1^{\text {st }} \mathrm{N}$. American symposium on landslides: 3-8 June 2007, Vail, CO, USA, pp:1414-1421.

Sadagah, B. H. (2008). Application of rockfall hazard rating system on rock slope cuts along a mountain road, South Western Saudi Arabia. The $10^{\text {th }}$ International symposium on landslides and engineered slopes, 30June4July 2008, Xian, China.

Sadagah, B. H. (2009). Rockfall hazard analysis on rock slope cuts: a case study from southern Saudi Arabia. The Proceedings of the third international conference on new developments in rock mechanics and engineering (NDRM 2009) and Sanya forum for the plan of city and city construction, Sanya, China

Sadagah, B. H. (2010). Slope stability analysis at selected part of Al-Hada mountainous road in western Saudi Arabia". AIMM 10, 30 May- 3 June, Seol, S. Korea

Santi, P. M., Christopher, P. R., Jerry, D. H., \& Jessica, I. S. (2009). Modification and statistical analysis of the Colorado rockfall hazard rating system. Engineering Geology, 104(1-2), 55-65. https://doi.org/10.1016/j.enggeo.2008.08.009

Saudi Geological Survey (SGS). (2017, May 1). Geology of Saudi Arabia. Retrieved from http://www.sgs.org.sa/English/Geology/Phanerozoic/Pages/default.aspx

Uribe-Etxebarria, G., Morales, T., Urarte, J. A., \& Ibarra, V. (2005). Rock cut stability assessment in mountainous regions. Environmental Geology, 48(8), 1002-1013. https://doi.org/10.1007/s00254-005-1323-1

Varnes, D. J. (1978). Slope movement types and processes. In: Schuster, R. L., \& Krizek, R. J. (eds) Landslide: analysis and control. Transportation research board, National research council, Washington, D.C., pp11-13.

Vásárhelyi, B. (2005). Statistical analysis of the influence of water content on the strength of the Miocene limestone. Rock Mechanics and Rock Engineering, 38(1), 69-76. https://doi.org/10.1007/s00603-0040034-3

Wong, C. K. L. (1998). The new priority classification systems for slopes and retaining walls. Geo Report No. 68. The Government of the Hong Kong special administrative region, p135

Wong, L. N. Y., Maruvanchery, V., \& Liu, G. (2016). Water effects on rock strength and stiffness degradation. Acta Geotechnics, 11(4), 713-737. https://doi.org/10.1007/s11440-015-0407-7

Woodard, M. J., \& Shakoor, A. (2005). Development of a rockfall hazard rating matrix for Ohio. In: Arnould, M. and Ledru, P. (eds.), Proceedings, Geoline 2005 - International symposium on geology and linear infrastructures, Lyon, France.

Wyllie, D. C. (1987). Rock slope inventory system. In: Proceedings of Federal Highways Administration (FHWA) rockfall mitigation seminary, $13^{\text {th }}$ Northwest geotechnical workshop, Portland, Oregon.

Youssef, A. (2015). Landslide susceptibility delineation in the Ar-Rayth area, Jizan, Kingdom of Saudi Arabia, using analytical hierarchy process, frequency ratio, and logistic regression models. Environmental Earth Sciences, 73(12), 8499-8518. https://doi.org/10.1007/s12665-014-4008-9

Youssef, A., Al-Kathery, M., \& Pradhan, B. (2015a). Landslide susceptibility mapping at Al-Hasher area, Jizan 
(Saudi Arabia) using GIS-based frequency ratio and index of entropy models. Geosciences Journal, 19(1), 113-134. https://doi.org/10.1007/s12303-014-0032-8

Youssef, A., Maerz, N., \& Al-Otaibi, A. (2012). Stability of rock slopes along Raidah escarpment road, Asir Area, Kingdom of Saudi Arabia. Journal of Geography and Geology, 4(2), 48-70. https://doi.org/10.5539/jgg.v4n2p48

Youssef, A., Maerz, N., \& Fritz, M. (2003). A risk-consequence hazard rating system for Missouri highways. The $54^{\text {th }}$ highway geology symposium, Burlington, Vermont, 24-26 Sep, 2003, pp175-195.

Youssef, A., Pradhan, B., Al-Kathery, M., Bathrellos, G., \& Skilodimou, H. (2015d). Assessment of rockfall hazard at Al-Noor Mountain, Makkah city (Saudi Arabia) using spatio-temporal remote sensing data and field investigation. Journal of African Earth Sciences, 101, 309-321. https://doi.org/10.1016/j.jafrearsci.2014.09.021

Youssef, A., Pradhan, B., Jebur, M., \& El-Harbi H. (2015b). Landslide susceptibility mapping using ensemble bi-variate and multivariate statistical models in Fayfa area, Saudi Arabia. Environmental Earth Sciences, 73(7), 3754-3761. https://doi.org/10.1007/s12665-014-3661-3

Youssef, A., Pradhan, B., Pourghasemi, H., \& Abdullah, S. (2015c). Landslide susceptibility assessment at Wadi Jawrah Basin, Jizan region, Saudi Arabia using two bivariate models in GIS. Geosciences Journal, 19(3), 449-469. https://doi.org/10.1007/s12303-014-0065-z

\section{Copyrights}

Copyright for this article is retained by the author(s), with first publication rights granted to the journal.

This is an open-access article distributed under the terms and conditions of the Creative Commons Attribution license (http://creativecommons.org/licenses/by/4.0/). 